\title{
Relations Between Intangible and Tangible Culture on Example of Casimir-Historical Jewish District in Cracow
}

\author{
T. E. Malec \\ Istanbul Kemerburgaz University, Istanbul, Turkey
}

\begin{abstract}
In Jewish City in Casimir-historical district of Cracow, Jewish culture manifested its original architectural style based mostly on specific detail. Perception of this type of architectural detail depends, basically, on knowledge of the Jewish culture. Proper understanding of meaning of the Jewish architectural detail depends on complex relations between Jewish tangible and intangible culture. Nowadays, it is especially important, according to relatively fast revitalization of the district. All renovation works require specific approach taking into account differences based on cultural diversity. Moreover, the understanding of the Jewish architectural detail is strictly connected with both history of Jews and Poles. One thousand years of cohabitation allowed to understand the economical and, partially, social differences, but not cultural at whole. The main aim of the article is to present chosen cultural and non-cultural factors, affecting the perception of the Jewish architectural detail in Casimir.
\end{abstract}

Keywords: architectural detail, Jewish architecture, culture, Casimir

\section{Introduction}

The tangible culture of each nation is inseparable from its intangible culture. This relationship undergoes changes in time, although its basic rules remain fundamentally invariable. The invariability stems from the perception of culture as a complex phenomenon, characterized by specific regularity and repeatability. It should be emphasized that man - regarded both as a separable entity and a part of a community (Tatarkiewicz, 1986) - has always been an indispensable factor for culture maintenance and development.

The knowledge and technology, skills, customs and tradition, religion, all belong to non-material culture. The development of both intangible and tangible culture runs in a non-linear way. Moreover, some of intangible culture elements are subjected to particular attention of a defined society. Due to this reason their development may be relatively fast. In that case other elements of intangible culture are usually ignored and their significance for the social life is being consequently reduced. Artifacts and buildings are elements of tangible culture. Within one culture limits, the artifacts and buildings possess many common features which may occur at different intensity depending on users' requirements and notions, connected with the intentions of the creator, or with other less important factors.

The development of intangible culture is influenced by factors of inner and external nature. It must be stressed that the inner factors, after some time, lose their strength. When inner factors become weaker than before,

T. E. Malec, professor, Department of Engineering and Architecture, Istanbul Kemerburgaz University, Istanbul, Turkey. 
the environment - understood in a wide range of meaning — gains increasing importance. Radical changes may occur, resulting in at least a partial breakup with the previous style of life. In the case of the Jewish community in Poland, a telling example of the aforementioned situation, it has been the process of assimilation of the Jews to the Polish society.

\section{Influence of the Acculturation and Assimilation on the Jewish Art}

Until the end of the 18th century the Jews in the Polish-Lithuanian Commonwealth constituted a minority, not particularly liable to any integration with other nations. The maintenance of the ethnic and religious separateness was a matter of utmost importance for the Jewish community. This isolation was supported by the Jewish Diaspora, focused on absolute and unambiguous independence in the field of culture and religion, and, in consequence, on liberating Jewish districts from the power of municipal jurisdiction. The idea of total isolation was common in the Catholic Church, which took all measures to restrict the relations between such different worlds of the Jews and Christians (Piechotkowie, 2008). In connection with the above, infrequent assimilation processes started to develop relatively late - from the early 19th century, and, moreover, they were deprived of social acceptation character. Therefore, the assimilation of the Jews to the Polish culture was not planned on the Jewish society level. Nevertheless, it was planned on an individual level.

Attempting to incorporate the active life of "post - social classes"1 of the Polish society into their culture, the Jews were trying to become a part of all new social classes, but, especially, intelligentsia and middle or great bourgeoisie (Zieliński, 2008). The 19th and 20th century assimilation, connected with different forms of acculturation, resulted in the provision of the most influential modern Polish social classes which had a broad field of operation. This specific way of assimilation of the Jews indicates, explicitly, its reason, i.e. the will to develop by taking a more active part in the social life of the entire country. In view of close and comparatively small Jewish community, these possibilities were rather small. Accordingly, the main cause of the assimilation of the Jews to the Polish society was their urge to develop as human beings.

In the case of acculturation, the gist of the matter is an interpretation of willingness - or its absence- to preserve their own identity, as emphasized, on numerous occasions, by the Jews assimilating into the Polish society (Kijek, 2010). The differentiated context of identification was dependent on the social level of the assimilated persons; the higher the social level, the greater possibility of defining themselves as persons with Jewish roots. This was connected with a sense of security and individual independence of the people remaining a high or very high social and economical status. Acculturation related to the knowledge of the Polish language was directly linked to other cultural fields, including art. A crucial element of acculturation was the acceptance and understanding of all aspects of Polish culture, taking into account the differences between social classes. In this case, the term "all aspects" refers to those elements of culture which belong to a specific social class. It follows that members of different social classes had not only varied knowledge of culture, but they were also characterized by different level of understanding and active participation in cultural life, especially in terms of religion and art and, consequently, architecture. According to the foregoing, in the process of assimilation of the Jews to the Polish culture, the knowledge of architecture and its significance in everyday life, reflected the

\footnotetext{
${ }^{1}$ According to profound changes in the organization of social life, leading to the decline of certain social classes, for example the nobility ("szlachta").
} 
meaning of architecture for the intelligentsia and the bourgeoisie.

The intelligentsia began to form, and, eventually, to develop in the 19th century as a social class specific for Eastern European civilization. In principle, the Polish intelligentsia consisted of impoverished nobilities and some educated townsmen, who had little influence on material space due to their feeble economic status. The influence of the intelligentsia on making the decisions connected with the architectural spatial changes was either small or none. Furthermore, the idea of a specific social and cultural role of the intelligentsia did not predestine this social class to an active participation in the creation of material space. In this particular case, the focus of all members of that social class on propagating the intangible culture among the lower social classes, even concerned with art, modifying the customs and tradition, and humanistic attitude to religious issues-were all aspects not reflected in architecture, especially in the 19th and early 20th century, also partly due to the loss of Poland's political and economic independence during this period. Excluding few architects, the intelligentsia did not develop the skills necessary for planned, physical intervention into space. The acquisition of these skills by the intelligentsia, then regarded as very dangerous for the status quo of the social class, was not welcome by foreign rulers. In this way, the assimilation of the Jews to the Polish culture also encountered difficulties. To recapitulate the foregoing, the fact of belonging to the intelligentsia enabled the development of a perception of art, but — due to the economic situation—was not a favorable factor that could exert a significant influence on architecture, including architectural detail.

For the bourgeoisie, the possibilities of creating architectural space were greater. Obtaining big financial resources, supported by intensions of fortune development and willingness to emphasize their increasing social position and charitable activity, were all important factors contributing to shaping their relations with the surrounding space. Unlike the intelligentsia, this social class had a real influence on the decisions concerning architectural space. This gave rise to establishing numerous urban and suburban residences. Among members of the bourgeois assimilated to the Polish culture, it was really popular to establish schools, hospitals, social and cultural utility buildings. In the above mentioned cases, architectural details played an important role indicating assimilation - as they made direct references to details typical of other Polish urban districts.

The above-mentioned relation between the assimilation to the Polish culture and the significance of art and architecture, applied to those of the Jews who decided to start this process. However, a considerable part of the Jewish community did not decide to assimilate. In that case, the role of art and architecture and their perception belonged, entirely, to the Jewish culture. Accordingly, a question may be posed: What was the way of artistic and architectural perception and comprehension of art in the Jewish culture?

\section{Judaism and Architecture}

Judaism was established as a religion in the second millennium BC and has been developing since that time. It is a very complex system, directly influencing all fields of life. Especially, in the very first phases of its existence, in comparison to other religions, Judaism was characterized by the belief in one, non-corporal God. Having no common points with matter, God cannot be showed in the sphere of human imagination. Thus, a crucial element of Judaism is the prohibition of making images of God and humans (Aniconism), and the conditional limitation of presenting images of animals and plants. The prohibition of making images of God and humans created in God's likeliness is explicit, whereas the visualization of animals and plants by itself is not 
wrong. However, there is a risk that some people can endow them with improper meaning. In the light of the above statement, placing all representations of nature is acceptable, practically, especially in sacral aspects (synagogues, houses of prayers, cemeteries, etc.). Moreover, the context of their materialization has a strong and relatively explicit symbolic meaning.

In connection with the above, the application of animal and plant motifs should be clearly associated with a proper way of thinking about them, in accordance with the defined space. In compliance with the need to preserve the correctness of reading the sacred symbols, their understanding in Judaism has not changed over the centuries. All the symbols seen in the kirkuts ${ }^{2}$ (above the entrances or in the upper parts of the matzevas ${ }^{3}$, e.g.), common in use from the 17th century, may be divided into the main categories: symbols presenting virtues of the humans and nation, symbols of sex and age, roots of the deceased, death and eternity, and the symbols of profession (Dylewski, Olej-Kobus, \& Kobus, 2010).

Letters have always played significant role in the Jewish architecture. The first alphabets were created from the conversion of the pictograms into equivalents of single sound symbols. They were derived from the North Semitic consonantal writing system, established in the Levant in the first half of the second millennium BC. Pursuant to this system, the first Phoenician alphabet based on consonants was formed, which, in time, gave rise to the early Hebrew alphabet (Bruce-Milford \& Wilkinson, 2010).

The creation of letter words, shown in the form of inscriptions, was a partial solution to the prohibition of presenting images of God and humans. It should also be noted that written information occurred relatively often, and contributed to the spread of reading and writing skills.

The symbolism of the numerals has very important meaning for Kabbalah ${ }^{4}$, one of the essential elements of the Jewish mysticism. In order to search for a hidden meaning of the relations between Hebrew alphabet letters, Sephirot $^{5}$, and numerals Gematria ${ }^{6}$ were established-numerological systems characterized by advanced complexity, creating possibilities for a broad interpretation. Assigning the numeral values to the letters, creating their defined meanings, enabled their use in space in order to achieve some expected results. Depending on the number of the architectural details (windows, bossages, etc.) connected with the numerals and according to kabbalistic knowledge, there was a possibility of influencing human life, as well as current, and future events.

\section{Jewish Architecture in Casimir}

Complex relation between intangible and tangible culture was especially visible in the Jewish community. A

\footnotetext{
${ }^{2}$ Kirkut (also kierkov, Germ. Kirche Hof, Eng. churchyard) - Polish name of the Jewish cemetery.

3 Matzeva- Hebrew and Polish name of the Jewish funerary stele, standing upright, usually a completed semicircular table put at the "legs" of the grave and turned into Jerusalem direction. Another form of burial is a sarcophagus (tumba), more common in Poland among the Sephardic Jews, and ohel (tent).

${ }^{4}$ Kabbalah-philosophical system developed in the 20th century. Kabbalists sought inner meaning of life by deciphering the structure hidden behind a reality visible for most people, by understanding the relationships between the divineworld and the human world. The apogee of the Kabbalah development, especially popular among the exiles from Spain and their descendants, falls on the sixteen century. It is worth mentioning that the development of the kabbalistic system is Chassidism (Elior, 2009).

${ }^{5}$ Sephirot-ten emanations in Kabbalah, considered as the steps illuminating the Divine plan. The emanations symbolize all the aspects of the relation between God and human. Symbolically, they are presented as elements of the Tree of Life. Sephirot is regarded as the most important part of Kabbalah's idea.

${ }^{6}$ Gematria - a Jewish numerological system which assigns numeral value to each letter, word or phrase; according to this it is possible to understand some relations between the phrases with the same number of letters, influencing directly human life, etc. The word has been extant in English since the second half of the seventeen century in connection with translation of the works of the Italian philosopher, Giovanni Pico della Mirandola.
} 
big importance given to religion closely connected to customs and tradition, determined its extraordinary development. The Jews from Galicia, unlike the Jews coming from other parts of Poland, since the beginning of the 19th century were developing art, particularly music, painting, and sculpture. There were specific opportunities for the Jewish community development in this area. The knowledge of these arts significantly influenced the perception of architecture. Nevertheless, the Jewish religion connected with widely understood knowledge and financial capabilities were of crucial importance in the creation of tangible culture in Cracovian Casimir, including architecture. Casimir (Pol. Kazimierz, Germ. Kazimir) was medieval auxiliary town of Cracow, where established in 1495 the Jewish settlement. Since the abolition of the separation between the Jewish town and Polish districts at the end of the 18th century Casimir has been usually recognized as a Jewish quarter of Cracow. Before the Second World War it was inhabited by a big Jewish community.

The creation of architecture in terms of the social aspects results, in particular, from designer's knowledge, skills and experience. In the case of the Jewish community, remaining over two thousand years in the Diaspora, the knowledge of buildings and construction skills were neither developed nor preserved. Thus, the experience derived from systematic design and building works was rare among the Polish Jews. This is due to three main reasons: lack of their own country, and the consequent absence of the function of art by means of which the society could identify itself, relatively low importance of the value of buildings for the Jewish world-view, frequent changes of places of residence.

The lack of the country, and the preservation of both national and religious identity, were emotionally implied as a focus on the problem of coming back to the Promised Land, including the reconstruction of the Temple. Frequent need of changing the place of residence throughout history was not a condition conducive to the necessity of developing buildings identifiable with a place of occupancy. Strong, psychological bonds with the place of occupancy entail opportunities for making permanent, large-scale changes in the spatial characteristics of the surroundings. Until the 20th century, the opportunities for of reactivating the Jewish state were small, thus there was also no urgent need to collect the knowledge of buildings and to develop the related skills. The circumstances changed with the beginning of modernism in culture, especially both in art and architecture, and with increasing religious tolerance in Poland.

Up to that time, Jewish investors in Poland hired Christian designers, craftsmen and workers. Hence, that is a reason of great similarity between the buildings in Jewish and other districts of Krakow. The Old Synagogue in Casimir, established in the 15th century as one of the oldest synagogues in Poland, after undergoing Matteo Gucci reconstruction in 1557-1570, was endowed with the Gothic-Renaissance exterior. Other Polish synagogues, located not only in Cracow, were subjected to similar changes.

The same rule was applicable to secular architecture. However, not all elements that were proper for Christian architecture could be duplicated in buildings inhabited by the Jews. One of the differences, for instance, resulted from the prohibition of making images of God and humans and thus - the absence of such types of sculpture. Another equally important discrepancy was the application, not only in the spatial context, of typical Jewish architectural detail, including representation of the images of Menorah, the Star of David, Shofar, and references to synagogue architecture. According to the reticence towards the use of symbolical architectural details conditioned by the religious doctrine, the quantity of the above-mentioned presentations is relatively small. 
An important difference between the Christian part of Cracow and the Jewish Casimir is the reference of the latter to the Moorish architecture, characteristic both for secular and sacral architecture. The implementation of the Moorish style was sentimental, and its source derived from the Jews who had come directly from Spain and settled in Casimir (Kryciński, Olej-Kobus, \& Kobus, 2011) in the 16th century, and from their ensuing need to present independent Jewish culture. Instead of remaining under the Spanish control of the Catholic Monarchs, most of the buildings had been constructed by Moriscos. Bearing in mind examples of outstanding Spanish architecture of the 16th century-constructed thanks to the knowledge, technology and skills of the Muslims - the emigrating Jews began to regard the Moorish style as an important part of their own culture.

\section{Conclusions}

To sum up the foregoing, Jewish architectural details from the beginning of the existence of the Jewish Town, up to its end, were very rarely represented. The reason for this was, on the one hand, the Jewish religion strongly committed to avoiding representations of the God and humans, but, on the other one - the financial capacity of investors, people of Jewish origin professing Judaism and assimilated to the Polish society. It follows that any attempt to recreate the Judaic architectural details and all the implements of elements referring directly or indirectly to the Jewish culture required, to say the least, exceptional attention of an investor and systematic consultations with experts in this field. Thus, an unambiguous interpretation of the meaning of an architectural detail in terms of the Jewish culture is possible.

Therefore, a necessary condition for proper perception of the Jewish architectural details is such a degree of the knowledge of the Judaic culture that enables its correct interpretation. Nowadays, in the period of the intense revitalization of Cracovian Casimir and its increasing touristic significance, such conscious approach to restoration, especially in terms of architectural detail, seems to be particularly important.

\section{References}

Bałaban, M. (1920). Z historii Żydów w Polsce. Szkice i studja [From the history of the Jews in Poland. Sketches and studies]. Warszawa: B-cia Lewin-Epstein i S-ka.

Benjamin, A. (2011). Present Hope. Philosophy, Architecture, Judaism. London and New York: Routledge.

Dylewski, A., Olej-Kobus, A., \& Kobus, K. (2010). Judaica. Warsaw: Carta Blanca.

Elior, R. (2009). Mistyczne źródła chasydyzmu [Mystic sources of Chassidism]. Krakow-Budapest: Austeria.

Gombrich, E. H. (2009). Zmyst porzadku. O psychologii sztuki dekoracyjnej [The sense of order: A study in the psychology of decorative art]. Kraków: Universitas.

Kijek, K. (2010). Polska akulturacja, żydowski nacjonalizm? Paradygmat "akulturacji bez asymilacji” a świadomość polityczna międzywojennej młodzieży żydowskiej na podstawie autobiografii YIVO [Polish acculturation, Jewish nationalism? The paradigm of "acculturation without assimilation" versus political consciousness of the Jewish youth pursuant to YIVO autobiography in the period between the two World Wars]. In K. Zieliński (Ed.), Wokót akulturacji i asymilacji Żydów na ziemiach polskich [Around acculturation and assimilation of the Jews on the Polish territory] (pp. 85-112). Lublin: Wydawnictwo Uniwersytetu Marii Curie-Skłodowskiej.

Kopaliński, W. (2012). Stownik symboli [A dictionary of symbols]. Warszawa: Oficyna Wydawnicza Rytm.

Kryciński, S., Olej-Kobus, A., \& Kobus, K. (2011). Zabytki kultury żydowskiej w Polsce. [Monuments of the Jewish culture in Poland]. Warsaw: Carta Blanca.

Namenyi, E. (1960). The essence of Jewish art. New York: T. Yoseloff.

Piechotkowie, M. i K. (2008). Krajobraz z menora [Landscape with menorah]. Wrocław: Zakład Narodowy im. Ossolińskich. Sperber, D. (1996). Explaining culture: A naturalistic approach. Oxford: Blackwell Publishers. 
Tatarkiewicz, W. (1986). Cywilizacja i kultura [Civilization and culture]. In W. Tatarkiewicz(Ed.), O filozofii i sztuce (pp. 147-158). Warsaw: PWN.

Zieliński, K. (Ed.). (2008). Wokól akulturacji i asymilacji Żydów na ziemiach polskich [Around acculturation and assimilation of the Jews on Polish territory]. Lublin: Wydawnictwo Uniwersytetu Marii Curie-Skłodowskiej. 